\title{
The Eemian - local sequences, global perspectives: introduction
}

\author{
Thijs van Kolfschoten ${ }^{1} \&$ Philip L. Gibbard ${ }^{2}$
}

${ }^{1}$ Faculty of Archaeology, Leiden University, P.O. Box 9515, 2300 RA LEIDEN, the Netherlands; Corresponding author; e-mail: T.van.kolfschoten $@$,arch.leidenuniv.nl

${ }^{2}$ Godwin Institute of Quaternary Research, Department of Geography, University of Cambridge, Downing Street, CAMBRIDGE CB2 3EN, England; e-mail:plg1@cus.cam.ac.uk

Received: May 2000; accepted in revised form: 20 June 2000

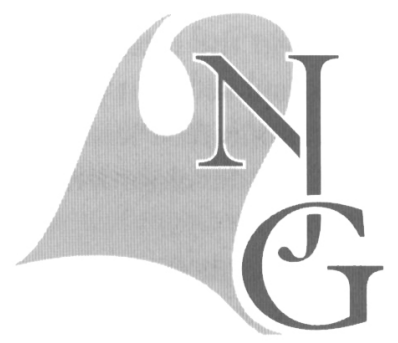

\section{The history of this special issue}

The history of this volume goes back to a $1973 \mathrm{IN}-$ QUA congress in New Zealand, where an INQUA Commission of Stratigraphy working group on major subdivisions of the Pleistocene was established. The Pleistocene series/epoch was hitherto generally subdivided into the Lower/Early, Middle and Upper/Late Pleistocene (see, among others, Zeuner, 1935, 1959) but the boundaries between these subseries/subepochs were not formally defined. The boundary between the Early and Middle Pleistocene was, in the European literature, put at the base of the Cromerian Complex (Zagwijn, 1963) or at the Brunhes/Matuyama magnetic boundary (Richmond, 1996). In the literature, there is more consensus about the position of the Middle/Late Pleistocene boundary. This boundary was placed almost without exception at the base of the Eemian stage.

Although there was consensus about where to define the Middle/Late Pleistocene boundary, the INQUA Commission of Stratigraphy was aware of the fact that consensus alone is not enough, however, to formalize a stratigraphical boundary. Based on global standard stratigraphical rules (cf. Holland, 1998) a 'global standard stratotype and point' (GSSP) (Salvador, 1994) must be defined for formal chronostratigraphical boundaries. Although there are many geological sections showing the transition from the penultimate glaciation to the last interglacial around the world, it wablished decineded Gambridge Univetsity Press gation and discussion on the Middle/Late Pleistocene boundary on the original type area of the Eemian in the Netherlands. The Eemian sequence was often used as reference and furthermore the term 'Eemian' was widely used to identify the last interglacial far beyond western central Europe. Examination of the available data from the Eemian type area showed that a re-evaluation of existing data and collection of critical new data were needed to define an unambiguous stratigraphical boundary. Although the identification of boundaries is central to stratigraphical subdivision, it is nevertheless the Eemian as an entity that is of particular interest for understanding the development of a complete interglacial cycle.

\section{The Eemian as a stage}

The 'Eemian' is the term used to identify the last interglacial temperate period, the first stage of the Late Pleistocene. It is a formal chronostratigraphical unit the base of which, following biostratigraphical convention in NW Europe, is taken at the point where tree pollen replaces that of non-tree pollen in pollen diagrams from the sediments. The upper limit of the stage is defined, again following standard stratigraphical convention, by the base of the succeeding stage, the Weichselian, where the opposite transition occurs, i.e. where tree pollen is replaced by non-tree pollen (cf. Jessen \& Milthers, 1928).

The Eemian is often regarded as a typical interglacial event in the sense that it is characterized by 
high eustatic sea level, retreat to minimum size of global ice sheets and an establishment of biotic assemblages that closely parallel those of the present Holocene interglacial. Subdivision of the stage in north-west Europe and beyond is based on pollen assemblages, first proposed in the classic work of Jessen \& Milthers (1928) in Denmark and north Germany, and modified by many since (among others: Zagwijn 1996). This vegetational development reflects the typical cycle of vegetational change from pioneer trees including Betula and Pinus, through the deciduous broad-leafed trees, to the arrival of Taxus, Carpinus and Picea in the second half of the stage and culminating in the return of Betula and Pinus as precursors to the subsequent glacial stage. This cyclic change, so typical of later Pleistocene interglacials, is also reflected in the development of the soils, as noted by Iversen (1958).

The stage was originally defined as a formal name for sequences of sand and fine shell-bearing sediments in the Amsterdam, and latterly the Amersfoort areas, of the Netherlands. Here, these fossiliferous sediments rest on glacial diamicton and associated sediments of the preceding Saalian glaciation, the latter shown by German scientists (among them Keilhack; in Woldstedt, 1929: 129) to be the penultimate glaciation of the Scandinavian ice sheet. Therefore, the fossiliferous Eemian beds must represent a temperate event, post-Saalian but predating the glacial and periglacial deposits of the subsequent or last glaciation, the Weichselian. The Eemian beds must therefore represent the last interglacial.

Estimates of the duration of the stage vary somewhat but on the basis of a combination of counting of sediment annual rhythmites and extrapolation for the second half of the event, the length has been estimated by Müller (1974) from the Bispingen locality in Niedersachsen, Germany to be 11,500 years.

Beyond western central Europe, the interglacial climatic event has been assigned a variety of names, including the Riss/Würm interglacial (Alps), Ipswichian (Britain), Mikulino (European Russia), Murava (Byelorussia), Merkine (Lithuania), Felicianova (Latvia), Tepsankumpu (Finland), Prangli (Estonia), and Sangamonian (North America) on the land. The generally agreed equivalent in the ocean-basin sediments is marine isotope substage (MIS) 5e. Assumptions that these events are to a greater or lesser extent the direct equivalent of the Eemian stage sensu stricto lies at the heart of global correlation schemes. Whilst this may be accurate in broad terms, it remains to be demonstrated that the boundaries of these variously defined units are in fact coeval. Indeed, in the light of recent discoveries, arising from attempts to cross-cor- relate between the terrestrial and ocean facies, it is readily apparent that this assumption is invalid (Sanchez-Goñi et al., 2000 - this issue). The continual pressure to develop ever higher-resolution stratigraphies throws this problem into high relief as a topic of considerable importance for future research.

Today the Eemian is represented not only in coastal marine sediments, but in a vast range of depositional situations, from the deep sea through shelf, littoral, estuarine to continental settings, including fluvial, lacustrine, spring and paludal environments. The temperate event is also recorded in weathering and pedological sequences. Its recognition in ice cores, where potential climatic oscillations were first recognized, has sporned considerable activity in which researchers, particularly in the North Atlantic region, have re-evaluated sequences in the light of these discoveries. Some discoveries have confirmed the presence of minor climatic oscillations (see, among others, Seidenkrantz et al., 1995; Maslin \& Tzedakis, 1996), whilst others have dismissed these ideas and rigorously defended the view that the interglacial climates remained broadly stable (among them Litt et al., 1996). Whatever the correct answer, the obvious implication of the discovery of possible climate oscillations is their relevance to future Holocene climate. Many have adopted the Eemian as a model for the world's immediate greenhouse future. The validity of its use is questioned, however, by Loutré \& Berger (in press) based on differences of insolation. Whilst this may be correct, the problems of recognizing, correlating and even finding older events in many parts of the world means that the Eemian will remain the primary analogue for the present interglacial for the foreseeable future.

\section{The NITG project and the SEQS meeting}

Discussion of the delimitation and identification of the Eemian at the 1995 INQUA Congress in Berlin led to the then Geological Survey of the Netherlands (Rijks Geologische Dienst; latterly the Netherlands Institute for Applied Geoscience -TNO) being requested to re-investigate the type area. This was initiated to locate a suitable global standard stratotype and point (GSSP) or golden-spike locality for the Eemian basal boundary. This boundary is coincident with the Middle/Upper Pleistocene subseries boundary by definition. The Subcommission on European Quaternary Stratigraphy (SEQS) was simultaneously asked to play an intermediary, stimulating and supportive role in this process.

NITG-TNO accepted the invitation and decided to re-investigate and re-evaluate not only the old data 


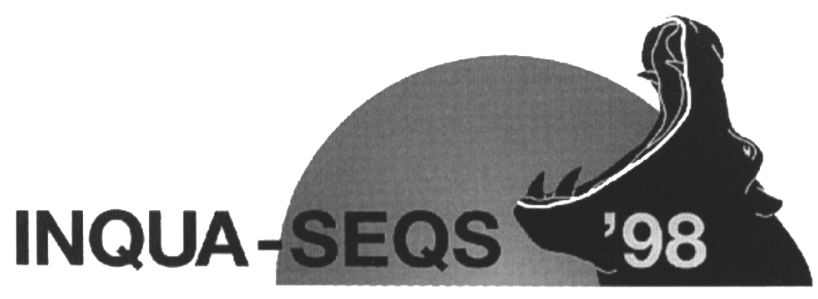

Fig. 1. Conference logo: The Eemian - Local sequences, global perspectives.

but also to drill and sample a new borehole in the Amsterdam basin (Amsterdam-Terminal). Thus, NITG-TNO began the Eemian project, one of their major scientific projects of the past few years. Consultations between the SEQS and NITG-TNO resulted in the establishment of an external advisory board and an intra-INQUA-congress programme in which the SEQS would concentrate its activities on the Late Pleistocene. The 1997 INQUA-SEQS meeting took place in Lithuania and was entitled 'The Late Pleistocene in Eastern Europe: stratigraphy, palaeoenvironment and climate'. A second meeting, organised in co-operation with NITG-TNO, entitled 'The Eemian; local sequences, global perspectives' (Fig. 1) was held in 1998 at Kerkrade (the Netherlands). At the latter meeting, the results of the NITG-TNO Eemian project were extensively presented as lectures and posters and discussed among the 120 participants from 19 different countries. Additional papers and posters dealing with information from throughout Europe and beyond were also presented. An excursion and a wide-ranging discussion on topics including the duration and climatic history of the Eemian completed the symposium.

In order to provide access to the data presented, in particular the new information from the Eemian type area, it was decided to prepare a volume that combined contributions from invited authors representing different disciplines and covering different geographical parts of Europe with that detailing NITG-TNO project results. An extensive list of 126 pages of references of relevant publications on Eemian deposits and their fossil contents, produced by Meijer (1998), was given to the meeting participants. Because of its length, this volume has not been incorporated in this issue. The data are, however, available on the internet.

\section{The result: the present issue}

The first four papers in the present issue are related to the NITG-TNO Eemian project. The first (Bosch et al.) is a historical review of recent research in the type area. The next one (De Gans et al.) deals with the regional stratigraphy of the sediments in the Amsterdam glacial basin. The sequence in the Amster-
dam-Terminal borehole is extensively described by Van Leeuwen et al. Finally, Cleveringa et al. present a re-evaluation of pre-existing and recent new data on the Eemian stratotype locality at Amersfoort. As well as providing an example of what can be achieved in local geological reconstruction, this study sets a foundation for regional investigations of neighbouring regions and areas beyond.

The NITG-TNO investigations are subsequently placed within a continental framework by Turner, in his review of the stratigraphy and palaeobotany of the Eemian of northern Europe; details of the Alpine region are then summarised by Drescher-Schneider. Turning to the faunal evidence, Meijer \& Preece review the occurrence of the mollusc, Corbicula, in the NW European Pleistocene; a genus which apparently does not occur in the Eemian but was abundant in some previous interglacials. The coleopteran assemblages from southern England indicate that mean July temperatures in the area during the early part of the interglacial were $4^{\circ} \mathrm{C}$ higher than at present, according to Coope. The mammalian record from the Eemian of central Europe is summarised by Van Kolfschoten, whilst the human occupation during the Eemian is discussed by Speleers. The mammal assemblages of the East European Plain are presented by Markova, whereas Dodonov et al. present evidence from central Asia and the northern shore of the Black Sea. Haesaerts \& Mestdagh discuss a transect of soilstratigraphical localities stretching from Belgium to central Russia that demonstrate the link between pedosedimentary evolution and vegetation. The vegetational history of Sweden and Finland during the interglacial are compared and contrasted by Robertsson. The environmental reconstruction from the Baltic region is extended offshore by Seidenkrantz et al., who include discussions of climatic variability during both the late Saalian and the Eemian itself.

The topic of land/sea correlation and climatic variability is addressed by Sanchez-Goñi et al., who apply high-resolution palynology to a deep-sea core succession off the Iberian coast and conclude that the terrestrial Eemian stage is not the precise time-equivalent of MIS 5e. Climatic variability in southern Europe is also the theme of the final contribution, in which Tzedakis demonstrates the substantial regional diversity of vegetational records during the interglacial in Greece.

Overall, the contributions represent a compilation of data covering a vast region of Eurasia. The amount of information is remarkable when one takes into account that the interglacial event represents such a short time interval: the Eemian sensu stricto. represents only about $0.5 \%$ of the Quaternary. 


\section{Future research}

The collection of studies presented herein provides an exciting vision of the vast potential available to the Quaternary community from the integrated, multidisciplinary study of the Eemian interglacial at a variety of scales. This work offers a firm foundation on which to build a broad-scale framework for a Europe-wide understanding of the climatic and environmental development during the Eemian, as well as of its geographical variation. It also demonstrates the wealth of detail available from the study of single sites in critical areas. For the future, it is obviously important to continue integrating the evidence from specific regions into broader-scale reconstructions, including in particular data from the type area. A more complete picture of the botanical and faunal development during the Eemian offers the potential to cast new light on the discussion of the assignment of certain successions to the Eemian.

There is, however, as discussed before, still no formally accepted definition of either the beginning or the end of the Eemian stage. For the former, the situation is particularly embarrassing since it also represents the Middle/Upper Pleistocene subseries boundary. Recognition of the Amsterdam-Terminal borehole as the unit stratotype for the Eemian stage, and the Saalian/Eemian transitional boundary as the boundary stratotype, would offer a significant advance in the accuracy of the terrestrial European stratigraphical succession. In proposing adoption of these stratotypes, it is implicit that they may be superceded at a later date by what may be deemed to be more suitable successions from other environmental settings. This is because stratigraphy must be dynamic and reference sections should be selected to provide the most detailed and diverse information applicable for wide-ranging correlations. Such sections may potentially be upgraded to parastratotypes as appropriate, for instance in shallow-marine settings, an environment of increasing importance in the near future. Successions from these situations give us insight into the movement of water masses that appear to influence climatic variability at a regional scale. The exchange of water in the Baltic Sea between the North Sea and the White Sea, for example, had a profound influence on the environment and climate in northern Europe by comparison with the Holocene. These successions furthermore potentially provide intermediate stepping-stones for onshore/offshore correlation. Through the application of sequence stratigraphy, they provide important elements in the establishment of sea-level change histories for the interglacial, a necessary prerequisite for palaeogeographical reconstruction.

\section{Acknowledgements}

The editors would like to thank the editorial board of Geologie en Mijnbouw / Netherlands Fournal of Geosciences for their permission to publish the proceedings of the INQUA-SEQS meeting and in particular Dr. K. Kasse and Dr. A.J. van Loon for their assistance. We are grateful to the many people who have reviewed the contributions. Finally, we thank Dr $M$. Head for critically reading this introduction.

\section{References}

Bosch, J.H.A., Cleveringa, P. \& Meijer, T., 2000. The Eemian stage of the Netherlands: history, character and new research. In: Van Kolfschoten, Th. \& Gibbard, P.L. (eds.): The Eemian - local sequences, global perspectives. Geologie en Mijnbouw / Netherlands Journal of Geosciences 79: 135-145 (this issue).

Cleveringa, P., Meijer, T., Van Leeuwen, R.J.W., De Wolf, H., Pouwer, R., Lissenberg, T. \& Burger, A.W., 2000. The Eemian stratotype locality at Amersfoort in the central Netherlands: a reevaluation of old and new data. In: Van Kolfschoten, Th. \& Gibbard, P.L. (eds.): The Eemian - local sequences, global perspectives. Geologie en Mijnbouw / Netherlands Journal of Geosciences 79: 197-216 (this issue).

Coope, G.R., 2000. The climatic significance of coleopteran assemblages from the Eemian deposits in southern England. In: Van Kolfschoten, Th. \& Gibbard, P.L. (eds.): The Eemian - local sequences, global perspectives. Geologie en Mijnbouw / Netherlands Journal of Geosciences 79: 257-267 (this issue).

De Gans, W., Beets, D.J. \& Centineo, M.C., 2000. Late Saalian and Eemian deposits in the Amstradam glacial basin. In: Van Kolfschoten, Th. \& Gibbard, P.L. (eds.): The Eemian - local sequences, global perspectives. Geologie en Mijnbouw / Netherlands Journal of Geosciences 79: 147-160 (this issue).

Dodonov, A.E., Tchepalyga, A.L., Mihailescu, C.D., Zhou, L.P., Markova, A.K., Trubikhin, V.M., Simakova, A.N. \& Konikov, E.G., 2000. Last-interglacial records from central Asia to the northern Black Sea shoreline: stratigraphy and correlation. In: Van Kolfschoten, Th. \& Gibbard, P.L. (eds.): The Eemian - local sequences, global perspectives. Geologie en Mijnbouw/Netherlands Journal of Geosciences 79: 303-311 (this issue).

Drescher-Schneider, R., 2000. The Riss-Würm interglacial from west to east in the Alps: an overview of the vegetational succession and climatic development. In: Van Kolfschoten, Th. \& Gibbard, P.L. (eds.): The Eemian - local sequences, global perspectives. Geologie en Mijnbouw / Netherlands Journal of Geosciences 79: 233-239 (this issue).

Haesaerts, P. \& Mestdagh, H., 2000. Pedosedimentary evolution of the last interglacial and early glacial succession in the European loess belt from Belgium to central Russia. In: Van Kolfschoten, Th. \& Gibbard, P.L. (eds.): The Eemian - local sequences, global perspectives. Geologie en Mijnbouw / Netherlands Journal of Geosciences 79:313-324 (this issue).

Holland, C.H., 1998. Chronostratigraphy (global standard stratigraphy): a personal perspective. In: Doyle, P. \& Bennett, M.R. (eds.): Unlocking the stratigraphical record. J. Wiley \& Sons (Chichester): 383-392.

Iversen, J., 1958. The bearing of glacial and interglacial epochs on the formation and extinction of plant taxa. Uppsala Universitetet Årsskrift 6: 210-215.

Jessen, K. \& Milthers, V., 1928. Stratigraphical and palaeontologi- 
cal studies of interglacial freshwater deposits in Jutland and north-west Germany. Danmarks Geologisk Undersøgelse, II Raekke 48.

Litt, T., Junge, F.W. \& Böttger, T., 1996. Climate during the Eemian in north-central Europe - a critical review of palaeobotanical and stable isotope data from central Germany. Vegetation History and Archaeobotany 5: 247-256.

Loutré, M.F. \& Berger, A. (in press). Stage 11 as an analogue for the present interglacial. In: Van Kolfschoten, Th., Knudsen, K.L. \& Gibbard, P.L. (eds.): The Eemian interglacial: a global perspective. Journal of Global and Planetary Change.

Markova, A.K., 2000. The Mikulino (= Eemian) mammal faunas of the Russian Plain and Crimea. In: Van Kolfschoten, Th. \& Gibbard, P.L. (eds.): The Eemian - local sequences, global perspectives. Geologie en Mijnbouw / Netherlands Journal of Geosciences 79: 293-301 (this issue).

Maslin, M. \& Tzedakis, P.C., 1996 Sultry last interglacial gets sudden chill. Eos Transactions (American Geophysical Union) 77 : 353-345.

Meijer, T., 1998. References of relevant publications about Eemian deposits: a base for a European Eemian bibliography. SEQS Symposium (Kerkrade, the Netherlands, 1998): $126 \mathrm{pp}$.

Meijer, T. \& Preece, R.C., 2000. A review of the occurrence of Corbicula in the Pleistocene of North-West Europe. In: Van Kolfschoten, Th. \& Gibbard, P.L. (eds.): The Eemian - local sequences, global perspectives. Geologie en Mijnbouw / Netherlands Journal of Geosciences 79: 241-255 (this issue).

Müller, H., 1974. Pollenanalytische Untersuchungen und Jahresschichtenzählungen an der eem-zeitlichen Kieselgur von Bispingen/Luhe. Geologisches Jahrbuch A 21: 149-169.

Richmond, G.M., 1996. The INQUA-approved provisional LowerMiddle Pleistocene boundary. In: Turner, C. (ed.): The early middle Pleistocene in Europe. Balkema (Rotterdam): 319-326.

Robertsson, A.-M., 2000. The Eemian interglacial in Sweden, and comparison with Finland. In: Van Kolfschoten, Th. \& Gibbard, P.L. (eds.): The Eemian - local sequences, global perspectives. Geologie en Mijnbouw / Netherlands Journal of Geosciences 79: 325-333 (this issue).

Salvador, A. (ed.), 1994. International stratigraphic guide ( $2^{\text {nd }}$ ed.). International Union of Geological Sciences \& Geological Society of America (Boulder): $214 \mathrm{pp}$.

Sanchez Goñi, M.F., Turon, J.-L., Eynaud, F., Shackleton, N.J. \& Cayre, O., 2000. Direct land/sea correlation of the Eemian, and its comparison with the Holocene: a high-resolution palynological record off the Iberian margin. In: Van Kolfschoten, Th. \& Gibbard, P.L. (eds.): The Eemian - local sequences, global perspectives. Geologie en Mijnbouw / Netherlands Journal of Geosciences 79: 345-354 (this issue).

Seidenkrantz, M.-S., Kristensen, P. \& Knudsen, K. L., 1995. Marine evidence for climatic instability during the last interglacial in shelf records from northwest Europe. Journal of Quaternary Science 10: 77-82.

Seidenkrantz, M.-S., Knudsen, K.L. \& Kristensen, P., 2000. Marine late Saalian to Eemian environments and climatic variability in the Danish shelf area. In: Van Kolfschoten, Th. \& Gibbard, P.L. (eds.): The Eemian - local sequences, global perspectives. Geologie en Mijnbouw / Netherlands Journal of Geosciences 79: 335-343 (this issue).

Speleers, B., 2000. The relevance of the Eemian for the study of the Palaeolithic occupation of Europe. In: Van Kolfschoten, Th. \& Gibbard, P.L. (eds.): The Eemian - local sequences, global perspectives. Geologie en Mijnbouw / Netherlands Journal of Geosciences 79: 283-291 (this issue).

Turner, Ch., 2000. The Eemian interglacial in the North European plain and adjacent areas. In: Van Kolfschoten, Th. \& Gibbard, P.L. (eds.): The Eemian - local sequences, global perspectives. Geologie en Mijnbouw / Netherlands Journal of Geosciences 79: 217-231 (this issue).

Tzedakis, P.C., 2000. Vegetation variability in Greece during the last interglacial. In: Van Kolfschoten, Th. \& Gibbard, P.L. (eds.): The Eemian - local sequences, global perspectives. Geologie en Mijnbouw / Netherlands Journal of Geosciences 79: 355-367 (this issue).

Van Kolfschoten, Th., 2000. The Eemian mammal fauna of central Europe. In: Van Kolfschoten, Th. \& Gibbard, P.L. (eds.): The Eemian - local sequences, global perspectives. Geologie en Mijnbouw / Netherlands Journal of Geosciences 79: 269-281 (this issue).

Van Leeuwen, R.J.W., Beets, D.J., Bosch, J.H.A., Burger, A.W., Cleveringa, P., Van harten, D., Herngreen, G.F.W., Kruk, R.W., Langereis, C.G., Meijer, T., Pouwer, R.\& De Wolf, H., 2000. Stratigraphy and intergrated facies analysis of the Saalian and Eemian sediments in the Amsterdam-Terminal borehole, the Netherlands. In: Van Kolfschoten, Th. \& Gibbard, P.L. (eds.): The Eemian - local sequences, global perspectives. Geologie en Mijnbouw / Netherlands Journal of Geosciences 79: 161-196 (this issue).

Woldstedt, P., 1962. Über die Benennung einiger Unterabtielungen des Pleistozäns. Eiszeitalter und Gegenwart 3: 14-18.

Zagwijn, W.H., 1963. Pleistocene stratigraphy in the Netherlands based on changes in vegetation and climate. Verhandelingen Nederlands Geologisch Mijnbouwkundig Genootschap, Geologische Serie 21: 173-196.

Zagwijn, W.H., 1996. An analysis of Eemian climate in western and central Europe. Quaternary Science Reviews 15: 451-469.

Zeuner, F.E., 1935. The Pleistocene chronology of central Europe. Geological Magazine 72: 350-376.

Zeuner, F.E., 1959. The Pleistocene period. Hutchinson (London): $447 \mathrm{pp}$. 